\title{
Preliminary results of a French multi-centre audit on transmission-based precautions
}

\author{
M Giard ${ }^{1,2^{*}}$, M-A Ertzscheid ${ }^{3}$, N Garreau ${ }^{3}$, E Caillat-Vallet ${ }^{4}$, N Vernier ${ }^{5}$, D Landriu ${ }^{6}$, C Laland $^{7}$, D Zaro-Goni ${ }^{7}$, A Savey ${ }^{4}$ \\ , M Aupée ${ }^{3}$, Grephh (French group for infection control practice assessment)
}

From 3rd International Conference on Prevention and Infection Control (ICPIC 2015)

Geneva, Switzerland. 16-19 June 2015

\section{Introduction}

In addition to standard precautions, transmission-based precautions (TBP) aim to prevent cross transmission of micro-organisms from patient to patient or to healthcare workers $(\mathrm{HCW})$. In France, guidelines were updated in 2009 for contact precautions and in 2013 for droplet and airborne precautions.

\section{Objectives}

The objective was to assess TBP implementation in healthcare settings (HCS).

\section{Methods}

The study consisted in a mixed audit of procedures, resources and knowledge. It was conducted between January $1^{\text {st }}$ and December $31^{\text {st }} 2014$. Inclusion criteria were voluntary public and private hospitals in France. Self-assessment questionnaires were administered at two levels: institutional and HCW. At ward level, an external auditor observed how TBP were applied for each patient requiring them (organisation, supplies and environment). Data were computed online by each HCS. Results were given as a percentage of objectives attained at institutional and ward levels, and as percentages of correct answers attained at $\mathrm{HCW}$ level. Pooled scores were calculated by criteria.

\section{Results}

A total of 547 hospitals participated, including 6,148 patients requiring TBP, 129,514 HCW and 5,114 physicians. At institutional level, the alert system score was $81.5 \%$. In particular, 99.1\% of HCS had a procedure to follow concerning internal information in case of multidrug resistant bacteria (MDRB), $60.3 \%$ had an information system in case of re-admission of a MDRB patient. Moreover, $84.6 \%$ of HCS had a procedure to check whether TBP were implemented in case of MDRB, $91.6 \%$ of whom traced it. At ward level, $95.0 \%$ of the implemented TBP belonged to the appropriate category. The overall score was $84.2 \%$, going from $68.6 \%$ for prescription traceability to $92.2 \%$ for room organisation. Further analyses are ongoing and these results will be available in June 2015 (HCW level, stratifications by speciality).

\section{Conclusion}

Such a large participation will serve as a national reference leading to TBP promotion actions for security improvement at local and national levels, as announced in the French national programme on healthcare-associated infections prevention.

\section{Disclosure of interest}

None declared.

\section{Authors' details}

${ }^{1}$ CClin Sud-Est, Hospices Civils de Lyon, Lyon, France. ²Université Lyon 1, Villeurbanne, France. ${ }^{3} \mathrm{CClin}$ Ouest, Rennes, France. ${ }^{4} \mathrm{CClin}$ Sud-Est, Lyon, France. ${ }^{5} \mathrm{CClin}$ Est, Nancy, France. ${ }^{6} \mathrm{CClin}$ Paris-Nord, Paris. ${ }^{7} \mathrm{CClin}$ Sud-Ouest, Bordeaux, France.

Published: 16 June 2015

doi:10.1186/2047-2994-4-S1-P91

Cite this article as: Giard et al:: Preliminary results of a French multicentre audit on transmission-based precautions. Antimicrobial Resistance and Infection Control 2015 4(Suppl 1):P91.

${ }^{1}$ CClin Sud-Est, Hospices Civils de Lyon, Lyon, France

Full list of author information is available at the end of the article 